\title{
Bioedusiana
}

http://jurnal.unsil.ac.id/index.php/bioed

DOI: https://doi.org/10.37058/bioed.v6i1.2465

Bioedusiana

\section{Studi Kasus SMA di Banten: Proses Pembelajaran Biologi SMA Melalui Pendekatan Saintifik dalam Mengembangkan Keterampilan Pemecahan Masalah Siswa}

\section{Senior High School Case Study in Banten: High School Biology Learning Process Though a Scientific Approach in Developing Student Problem Solving Skills.}

\author{
Umaya Tri Anggraini ${ }^{1 *}$, Iing Dwi Lestari ${ }^{2}$, Aditya Rahman KN ${ }^{3}$, Usman ${ }^{4}$, Ika Rifqiawati ${ }^{5}$ \\ 12345 Program Studi Pendidikan Biologi Universitas Sultan Ageng Tirtayasa, J1 Raya Jakarta Km. 04 \\ Pakupatan, Serang, 42111
}

\begin{abstract}
Abstrak
Penelitian ini bertujuan untuk mengetahui bagaimana proses pembelajaran biologi SMA melalui pendekatan saintifik dalam mengembangkan keterampilan pemecahan masalah siswa SMA di Banten serta faktor penghambat pengembangan keterampilan pemecahan masalah pada implementasi kurikulum 2013. Metode yang digunakan adalah penelitian deskriptif kualitatif dengan metode studi kasus. Lokasi penelitian ini pada 7 SMA negeri di Banten. Sumber data dalam penelitian yaitu guru pelajaran biologi dan siswa kelas XI. Teknik pengumpulan data yang digunakan terdiri dari observasi, wawancara, dokumentasi dan angket respon guru dan siswa. Hasil yang didapat dalam penelitian ini yaitu hasil observasi memperoleh skor $65 \%$ termasuk dalam ketegori baik dan hasil kuesioner $76 \%$ termasuk dalam ketegori baik. Rata-rata skor yang didapat yaitu $71 \%$ dengan kategori baik Adapun faktor pengembangan keterampilan pemecahan masalah yaitu kurangnya literasi membaca, rendahnya motivasi belajar, rendahnya rasa percaya diri siswa, pelaksanaan pembelajaran masih menggunakan model konvensional, sarana prasarana yang kurang mendukung. Disimpulkan bahwa implementasi kurikulum 2013 untuk pengembangan keterampilan pemecahan masalah melalui proses pembelajaran dengan pendekatan saintifik pada 7 SMA negeri di Banten sudah berkategori baik walaupun terdapat faktor yang menghambat pengembangan keterampilan.
\end{abstract}

Kata kunci: Keterampilan Pemecahan Masalah, Kurikulum 2013, Pendekatan Saintifik, Pembelajaran Biologi Proses.

\begin{abstract}
This research intends to know how a biology learning process applies scientific approach to developing problem solving skills at senior high school and inhibiting factors for problem solving skills in the 2013 curriculum. The method used a descriptive qualitative research with a case study method. The location of this research is at 7 high schools in Banten. Sources of data in the study were biology teachers and class XI students. The data collection techniques used consisted of observation, interviews, documentation, and student \& teacher response questionnaires. The results obtained in this research are the results of observations obtained a score of $65 \%$ included in the good category and the results of the questionnaire $76 \%$ included in the good category. The average score obtained is $71 \%$ with a good category. The factors for developing problem solving skills lack of reading literacy, low learning motivation, low self-confidence of students, learning implementation still uses conventional models, and infrastructure that is less supportive. It was concluded that the implementation of the 2013 curriculum for the development of problem-solving skills through the learning process with a scientific approach at 7 high school schools in Banten was categorized as good even though there were factors that hindered skill development.
\end{abstract}

Keywords: Biology Learning Process; Curriculum 2013; Problem Solving Skills; Scientific Approach.

Article History

Received: December 19 ${ }^{\text {th }}, 2021$; Accepted: June $28^{\text {th }}, 2021$; Published: June $30^{\text {th }}, 2021$

Corresponding Author*

Umaya Tri Anggraini, Universitas Sultan Ageng Tirtayasa, E-mail: trianggrainiumaya@gmail.com

(C) 2021 Bioedusiana. This is an open access article under the CC BY-SA 4.0 license

(https://creativecommons.org/licenses/by-sa/4.0/) 


\section{PENDAHULUAN}

Kurikulum merupakan seperangkat rencana dan pengaturan tujuan, isi materi pembelajaran dan metode yang digunakan sebagai pedoman dalam melaksanakan kegiatan pembelajaran untuk mencapai tujuan pendidikan tertentu. Kurikulum yang berlaku saat ini pada sistem pendidikan di Indonesia adalah kurikulum yang direvisi tahun 2013 atau biasa disebut dengan kurikulum 2013 revisi. Pembelajaran pada kurikulum 2013 revisi secara tertulis menekankan pada pendekatan saintifik. Menurut Salim (2014) Pendekatan saintifik berarti konsep dasar yang menginspirasi atau melatarbelakangi perumusan metode mengajar dengan penerapan karakteristik yang ilmiah. Sedangkan, metode ilmiah merupakan prosedur yang dijalankan dalam pencarian kebenaran dengan cara kerja sistematis terhadap pengetahuan baru dan melakukan tinjauan kembali terhadap pengetahuan yang telah ada pada zaman dahulu (Salim, 2014). Pendekatan saintifik dapat mendukung pembentukan keterampilan abad 21 yang disebut 4C, meliputi collaboration (kolaborasi), communication (komunikasi), creative and innovative (kreatif dan inovatif), critical thinking and problem solving (berpikir kritis dan pemecahan masalah).

Problem solving atau pemecahan masalah merupakan bagian dari keterampilan untuk memecahkan suatu masalah (Sulasmono, 2012). Memecahkan masalah merupakan dasar untuk mengidentifikasi masalah, mempertimbangkan pilihan, dan membuat pilihan bijak untuk memecahkan masalah. Dengan menggunakan keterampilan pemecahan masalah dalam proses pembelajaran diharapkan mampu bersaing di era globalisasi dan mampu memanfaatkan kemajuan teknologi. Bahri et al., (2018) menyatakan bahwa perlunya keterampilan pemecahan masalah dalam proses pembelajaran karena menggunakan scientific approach, berpikir sistematis, logis, teliti dan teratur. Sehingga diharapkan siswa mampu belajar dengan aktif baik individu ataupun kelompok dalam proses memecahkan masalah.

Guru merupakan tenaga pendidik yang berperan sangat penting dalam proses pembelajaran. Menurut Kirom (2017) guru memiliki 3 peran fungsi utama pada proses pembelajaran yaitu, sebagai perencana, penyelenggara, dan evaluator. Proses kegiatan belajar mengajar perlu dirancang oleh guru agar dapat mengevaluasi siswa. Rancangan pembelajaran tersebut dimuat dalam bentuk RPP (Rancangan Proses Pembelajaran). Guru mata pelajaran biologi selain memberikan pembelajaran dalam bentuk teori, guru juga memberikan pembelajaran dalam bentuk praktikum. Tujuannya adalah untuk menambah pemahaman siswa dalam memahami materi pembelajaran. Sehingga, perlu perencanaan pembelajaran yang baik pada teori maupun praktik. Kemudian dalam mempersiapkan teori dan praktik perlu dikembangkan juga keterampilan pemecahan masalah siswa, karena sesuai dengan tuntutan pembelajaran di abad 21. 
Hasil wawancara Guru Biologi pada 7 sekolah SMA kelas XI di Banten yang dipilih berdasarkan sekolah yang terakreditasi A dan terdapat di daerah Kota dan daerah Kabupaten di Provinsi Banten. Hasil wawancara yakni hampir semua guru sudah mengetahui tentang keterampilan pemecahan masalah. Guru sudah mengimplementasikan dalam proses pembelajaran. Namun dalam mengimplementasikan KPM (Keterampilan Pemecahan Masalah) tersebut tidak terbilang mudah karena terdapat faktor yang menjadi penghambat berkembangnya keterampilan pemecahan masalah dalam pembelajaran biologi diantaranya yaitu minat siswa dalam membaca rendah, kurang termotivasi dalam belajar dan siswa terlihat pasif dalam proses pembelajaran karena sebagian guru masih terpaku pada pembelajaran yang konvensional seperti metode ceramah. Seharusnya implementasi pendekatan saintifik dalam proses pembelajaran menggunakan metode pembelajaran yang modern, seperti salah satu contoh model pembelajaran PBL (Problem Base Learning) yang terfokus pada siswa aktif untuk memecahkan suatu permasalahan, dimana dalam proses pembelajarannya siswa diberikan suatu permasalahan terkait materi pembelajaran kemudian siswa memecahkan permasalahan tersebut baik individu maupun kelompok. Jika metode pembelajaran masih terpaku pada metode konvensional maka akan berpengaruh terhadap hasil belajar siswa, seperti yang dikatakan oleh Mahdiyanto et al., (2017) penggunaan metode pembelajaran konvensional memiliki hasil belajar yang rendah dibandingkan menggunakan metode pembelajaran modern. Hal tersebut juga diperkuat dengan data dari hasil belajar siswa pada Ujian Nasional SMA/MA 2019 bidang IPA yang dimana terdapat mata pelajaran Biologi tingkat SMA. Hasil yang didapat untuk provinsi Banten yang hanya memiliki rerata Nilai UN untuk jenjang SMA/MA Bidang IPA sebesar 53,3 \%. Sedangkan provinsi DKI Jakarta sebagai provinsi terdekat menurut letak geografisnya dari provinsi Banten, memiliki rerata nilai Ujian Nasional SMA/MA Bidang IPA sebesar 66,9 \% (Puspendik, 2019).

Dari fakta hasil belajar yang sudah dijabarkan, dapat diartikan bahwa terdapat perbedaan hasil belajar yang cukup signifikan. Hal tersebut mengindikasikan bahwa terdapat proses pembelajaran yang salah sehingga memunculkan nilai kognitif yang rendah dan tentunya akan berpengaruh bagi siswa dalam keterampilan memecahkan masalah. Sama dengan apa yang dikatakan Veronica et al., (2018) bahwa keterampilan memecahkan masalah berdampak pada hasil belajar siswa. Keterampilan pemecahan masalah dapat mengatur dan mengontrol apa yang dipelajari oleh siswa contohnya yaitu keterampilan memahami ruang lingkup masalah dan menemukan informasi yang relevan untuk menyelesaikan suatu permasalahan. Apabila siswa sudah dapat memahami lingkup dari suatu masalah maka siswa dapat dengan baik memahami soal-soal materi pembelajaran. Sehingga siswa memperoleh nilai yang baik dari hasil belajar. Maka dari itu perlu adanya penelitian tentang bagaimana proses pembelajaran biologi SMA 
melalui pendekatan saintifik dalam mengembangkan keterampilan pemecahan masalah siswa SMA di Banten.

\section{METODE}

Penelitian ini menggunakan jenis penelitian kualitatif dengan metode studi kasus dan secara keseluruhan melakukan survei langsung ke 7 sekolah untuk mengumpulkan data penelitian. Menurut Bog dan Taylor (Moleong, 2016) metodologi kualitatif sebagai prosedur penelitian yang menghasilkan data deskriptif berupa kata-kata tertulis atau lisan dari orang-orang dan perilaku yang dapat diamati. Pelaksanaan penelitian ini pada bulan Oktober 2019 - Juli 2020. Adapun lokasi penelitian ini bertempat pada 7 sekolah yang ada di Banten, diantaranya SMAN $11 \mathrm{Kab}$. Tangerang, SMAN $20 \mathrm{Kab}$. Tangerang, SMAN 6 Kota Tangerang, SMAN 7 Kota Tangerang, SMAN 1 Pandeglang, SMAN 4 Pandeglang dan SMAN 1 Pamarayan. Subjek penelitian yang digunakan yaitu 7 orang guru bidang studi biologi dan 105 orang siswa/i kelas XI. Teknik pengumpulan data yang dilakukan adalah pengamatan proses pembelajaran (Observasi), Wawancara, Kuesioner berupa angket skala Likert dengan rentan skor 1-5 dan Dokumentasi berupa video proses pembelajaran di kelas. Indikator keterampilan pemecahan masalah yang diadaptasi dari Reys et al., (1998). Dimana terdapat 17 indikator keterampilan pemecahan masalah, kemudian peneliti memodifikasi menjadi 15 indikator pemecahan masalah. adapun indikator keterampilan pemecahan masalah sebagai berikut :

1. Mengidentifikasi masalah

2. Merumuskan masalah dalam bentuk pertanyaan

3. Memahami kata dalam konteks

4. Memilih masalah sendiri

5. Mendeskripsikan berbagai strategi

6. Mengidentifikasi asumsi

7. Mendeskripsikan masalah

8. Memberi alasan solusi

9. Memberi alasan strategi yang digunakan

10. Memecahkan masalah berdasarkan data dan masalah

11. Membuat strategi lain

12. Menggunakan analogi

13. Menyelesaikan masalah secara terencana

14. Mengevaluasi kualitas solusi

15. Mengevaluasi strategi sistematika. 
Analisis data menggunakan model Miles dan Huberman (2014), yang dimana setelah pengumpulan data penelitian. Tahap yang pertama adalah reduksi data merupakan suatu bentuk analisis yang dapat mempertajam, mengklasifikasi, membimbing, menghapus data yang tidak perlu dan mengatur data sedemikian rupa sehingga dapat menarik kesimpulan akhir dan memverifikasi (Miles \& Huberman, 2014). Setelah mengumpulkan dan mengategorikan semua data, maka perlu dilakukan reduksi dan disesuaikan dengan rumusan masalah dalam penelitian. Hasil reduksi data berupa catatan lapangan, catatan awal, ringkasan tambahan. Dengan cara ini, data yang direduksi akan tergambar dengan jelas dan lebih terfokuskan.

Tahap kedua yaitu penyajian data yang dimana data dapat disajikan dalam bentuk matriks, bagan, grafik, diagram, kategori dan hubungan antar teks naratif. Miles dan Huberman (2014) mengatakan bahwa teks naratif paling sering digunakan untuk menyajikan data dalam penelitian kualitatif. Tujuan penyajian data adalah untuk memudahkan dalam memahami data dan menarik kesimpulan. Representasi data selesai setelah selesai direduksi.

Tahap ketiga yaitu menarik kesimpulan. Menurut Miles \& Huberman (2014) proses penarikan kesimpulan harus ditunjang dengan bukti-bukti yang ada serta diverifikasi selama penelitian berlangsung. Penarikan kesimpulan dilakukan dari hasil temuan dan melakukan verifikasi data. Miles \& Huberman (2014) menyatakan bahwa penarikan kesimpulan harus ditunjang dengan bukti-bukti yang ada serta diverifikasi selama penelitian berlangsung. Kesimpulan yang diambil dengan cara ini adalah kesimpulan yang kredibel.

\section{HASIL DAN PEMBAHASAN}

Hasil

Hasil observasi proses pembelajaran melalui pendekatan saintifik dalam mengembangkan keterampilan pemecahan masalah (KPM) dilaksanakan pada 7 sekolah SMA Negeri yang berada di provinsi Banten. Pengamatan ini dilakukan di kelas XI pada awal proses pembelajaran sampai akhir proses pembelajaran dalam satu pertemuan. Adapun hasil yang didapat dari observasi proses pembelajaran, yaitu pada Tabel 1 . 
Tabel 1. Hasil Observasi Keterlaksanaan Proses Pembelajaran Biologi dalam Mengembangkan KPM di setiap Sekolah

\begin{tabular}{ccccc}
\hline \multirow{2}{*}{ Sekolah } & Skor (\%) & Guru & Skor (\%) & Siswa \\
& Kategori & Kategori \\
A1 & 45 & Cukup & 39 & Cukup \\
A2 & 87 & Sangat Baik & 81 & Sangat Baik \\
A3 & 71 & Baik & 68 & Baik \\
A4 & 87 & Baik & 87 & Sangat Baik \\
A5 & 87 & Sangat Baik & 84 & Sangat Baik \\
A6 & 58 & Cukup & 58 & Cukup \\
A7 & 84 & Sangat Baik & 74 & Baik \\
\hline
\end{tabular}

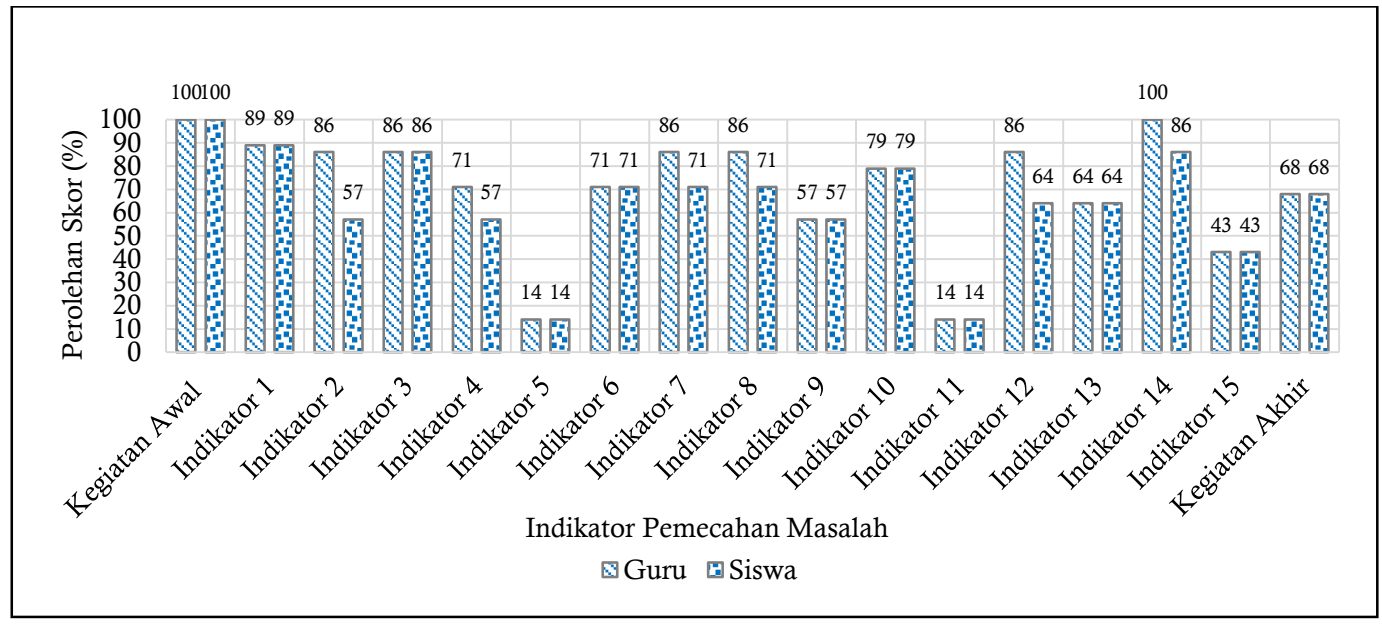

Grafik 1. Hasil Observasi Proses Pembelajaran Biologi Yang Mengembangkan KPM

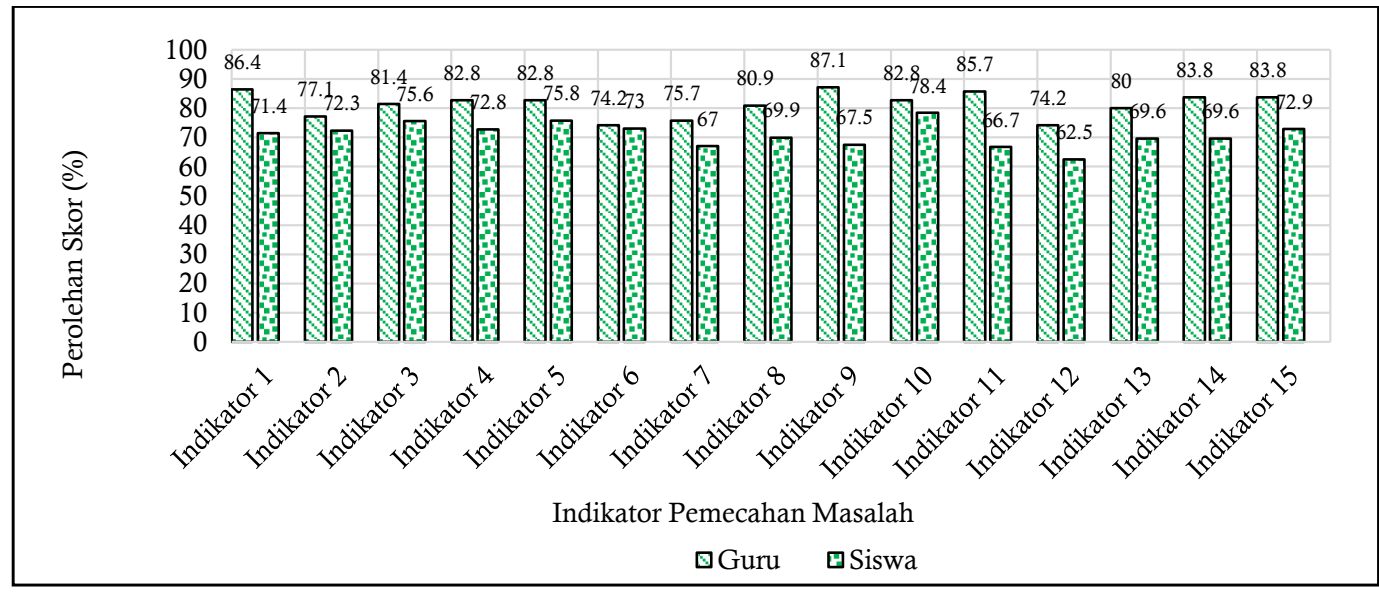

Grafik 2. Hasil Kuesioner Keterampilan Pemecahan Masalah 


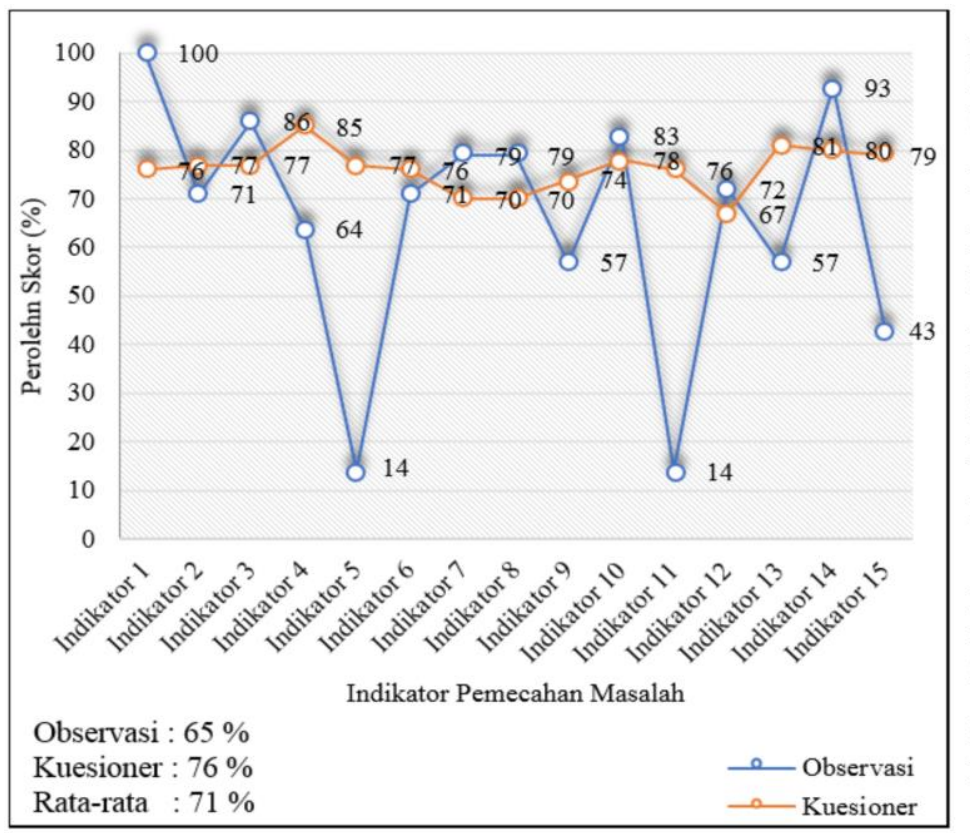

\begin{tabular}{|c|c|}
\hline & \\
\hline Indikator 1 & Mengidentifikasi masalah \\
\hline Indikator 2 & $\begin{array}{l}\text { Merumuskan masalah dalam } \\
\text { bentuk pertanyaan }\end{array}$ \\
\hline Indikator 3 & $\begin{array}{l}\text { Memahami kata dalam } \\
\text { konteks }\end{array}$ \\
\hline Indikator 4 & Memilih masalah sendiri \\
\hline Indikator 5 & $\begin{array}{l}\text { Mendeskripsikan berbagai } \\
\text { strategi }\end{array}$ \\
\hline Indikator 6 & Mengidentifikasi asumsi \\
\hline Indikator 7 & Mendeskripsikan masalah \\
\hline Indikator 8 & Memberi alasan solusi \\
\hline Indikator 9 & $\begin{array}{l}\text { Memberi alasan strategi } \\
\text { yang digunakan }\end{array}$ \\
\hline Indikator 10 & $\begin{array}{l}\text { Memecahkan masalah } \\
\text { berdasarkan data dan } \\
\text { masalah }\end{array}$ \\
\hline Indikator 11 & Membuat strategi lain \\
\hline Indikator 12 & Menggunakan analogi \\
\hline Indikator 13 & $\begin{array}{l}\text { Menyelesaikan masalah } \\
\text { secara terencana }\end{array}$ \\
\hline Indikator 14 & Mengevaluasi kualitas solusi \\
\hline Indikator 15 & $\begin{array}{l}\text { Mengevaluasi strategi } \\
\text { sistematika }\end{array}$ \\
\hline
\end{tabular}

Grafik 3. Persentase Perbandingan Hasil Observasi dan Hasil Kuesioner

\section{Pembahasan}

\section{Hasil Observasi}

Hasil observasi proses pembelajaran biologi pada kelas XI IPA dapat dilihat pada Tabel 1 bahwa sekolah yang memiliki skor tertinggi dalam mengembangkan keterampilan pemecahan masalah (KPM) adalah sekolah A4 dengan perolehan skor 87\% untuk guru dan siswa dengan kategori sangat baik. Skor ini menjadi yang tertinggi diantara skor lainnya. Hal ini dikarenakan ketika observasi kelas dilaksanakan, guru di sekolah A4 ini memaksimalkan proses pembelajaran yang mengembangkan keterampilan pemecahan masalah dan siswa terlihat aktif dalam proses diskusi. Berdasarkan hasil wawancara siswa di sekolah A4 bahwa guru sering memberikan tugas berupa studi kasus dan soal HOTS (Higher Order Thingking Skills). Menurut Lestari (2020) soal HOTS dapat mengukur kemampuan seseorang dalam mengaitkan konsep materi, kemudian mengukur kemampuan kognitif dalam memecahkan masalah serta menelaah ide secara kritis. Maka dari itu, memberikan soal HOTS kepada siswa dapat melatih tingkat berpikir siswa dalam mengembangkan keterampilan pemecahan masalah. Dari hasil observasi kelas, penugasan yang diberikan oleh guru nantinya akan dibahas bersama-sama dengan metode diskusi kelompok.

Sekolah yang memiliki perolehan skor terendah yaitu pada sekolah A1 dengan perolehan skor 45\% untuk guru dan 39\% untuk siswa dengan kategori cukup. Hal tersebut dikarenakan hasil yang teramati dalam proses pembelajaran, guru menyampaikan materi pembelajaran biologi menggunakan metode ceramah atau pembelajaran yang konvensional. Menurut Winarti et al., (2019) keterampilan pemecahan masalah dapat terlaksana ketika proses pembelajaran yang diterapkan memunculkan suatu pokok permasalahan atau pembelajaran yang berbasis masalah, salah satu contohnya yaitu penerapan model pembelajaran PBL (Problem Based 
Learning). Menurut Usman et al., (2017) memecahkan suatu masalah dengan berdiskusi merupakan salah satu bentuk proses pendekatan saintifik yang terdapat dalam kurikulum 2013. Oleh sebab itu, proses pembelajaran dengan cara berdiskusi dapat melatih kegiatan 5M (Pendekatan saintifik) yaitu mengamati, menanya, mengumpulkan data, menalar/mengasosiasi dan mengkomunikasikan.

Berdasarkan hasil observasi indikator (Grafik 1) yang memperoleh skor tertinggi adalah indikator ke-1 mengidentifikasi masalah pada guru dan siswa SMA negeri di Banten memiliki kategori yang sangat baik dengan perolehan skor $89 \%$. Indikator mengidentifikasi masalah ini menjadi indikator yang paling tertinggi dalam 15 indikator keterampilan pemecahan masalah. Hasil tersebut didapat dari kegiatan ketika guru memberikan apersepsi pembelajaran kepada siswa, kegiatan apersepsi ini bermacam-macam ada yang mengajukan pertanyaan kepada siswa dan ada juga yang menampilkan video pembelajaran. Kemudian guru menyiapkan pertanyaan terkait materi kepada siswa. Mengajukan beberapa pertanyaan kepada siswa dapat dinilai dapat mengetahui tingkat kemampuan mengidentifikasi masalah siswa (Laksana \& Dasna, 2017). Didukung dari hasil wawancara guru yang telah dilakukan, pada awal pembelajaran guru telah menyiapkan pertanyaan yang nantinya akan diajukan kepada siswa, dan didukung juga berdasarkan hasil kuesioner keterampilan pemecahan masalah guru pada indikator mengidentifikasi masalah memiliki kategori yang baik dengan skor $86,4 \%$ dan untuk siswa memiliki kategori baik dengan perolehan skor $71,4 \%$. Selanjutnya adalah Indikator ke-14 mengevaluasi kualitas solusi, guru selalu membimbing siswa dalam mengevaluasi kualitas suatu solusi pada saat proses diskusi dan di akhir pembelajaran. Ketika kegiatan akhir pembelajaran guru mengevaluasi dan mengulas kembali kegiatan pembelajaran dengan cara guru menunjuk siswa untuk membuat kesimpulan materi yang sudah dipelajari. Fitrianti (2018) mengatakan bahwa evaluasi merupakan kegiatan yang sengaja dilakukan dengan perencanaan yang matang untuk menentukan nilai yang diperoleh siswa setelah mengikuti rangkaian aktivitas pembelajaran. Sehingga kegiatan di akhir pembelajaran perlu diadakan evaluasi untuk mengetahui perkembangan pengetahuan siswa. Tingkat kemampuan dalam mengevaluasi kualitas solusi terbilang sangat baik dengan perolehan skor $100 \%$ untuk guru dan siswa sebesar $86 \%$ dengan kategori sangat baik.

Indikator pemecahan masalah yang mendapatkan perolehan skor terendah (Grafik 1) adalah pada Indikator ke-5 yaitu mendeskripsikan berbagai strategi. Berdasarkan hasil observasi, indikator mendeskripsikan berbagai strategi dalam proses pembelajaran biologi SMA di Banten terlihat sangat kurang baik dengan perolehan skor $14 \%$ untuk guru dan siswa. Indikator ini memiliki perolehan skor terendah dalam indikator keterampilan pemecahan masalah. Hal tersebut dikarenakan ketika mengamati proses pembelajaran di 7 sekolah tersebut peneliti melihat hampir seluruh siswa dan guru tidak memunculkan indikator mendeskripsikan berbagai 
strategi. Hal tersebut diduga tingkat berpikir kreatif yang masih rendah, karena dalam berpikir kreatif menurut Laurita et al., (2018) dapat memahami, menguasai suatu masalah yang ada dan mampu menyelesaikan masalah tersebut dengan berbagai cara secara bervariasi sesuai dengan ide. Selanjutnya adalah Indikator ke-11 membuat strategi lain. Berdasarkan hasil observasi indikator membuat strategi lain jarang sekali terlaksana karena pembelajaran yang diberikan tidak menuntut siswa untuk membuat strategi lain. Sebagian besar guru yang telah diamati pada 7 sekolah SMA Negeri di Banten dalam melaksanakan proses pembelajaran tidak memaksimalkan siswa untuk membuat strategi yang lain atau berbeda dari sebelumnya. Salah satu pengaruh dalam pengembangan keterampilan pemecahan masalah siswa yaitu budaya belajar yang tidak mendorong atau kurang memberikan kesempatan kepada siswa untuk bereksplorasi dan melakukan berbagai penyelidikan dari berbagai sudut pandang terhadap masalah yang dihadapi. Ketika itu dibiarkan maka tidak akan membuat siswa terbiasa dan terampil memecahkan masalah. Sehingga siswa juga akan memiliki tingkat kemampuan dalam membuat strategi lain yang rendah menurut Napitupulu (2008) guru seharusnya memperlihatkan bagaimana masalah dipecahkan dengan berbagai strategi yang dapat diterapkan untuk memecahkan beberapa masalah.

\section{Hasil Kuesioner Keterampilan Pemecahan Masalah}

Berdasarkan Grafik 2 keterampilan guru dalam memecahkan masalah memiliki tingkat kategori sangat baik dengan perolehan skor $81,3 \%$. Hal tersebut terlihat dalam proses pembelajaran bahwa guru telah membimbing siswa dalam memecahkan suatu permasalahan saat proses pembelajaran dimulai. Selain itu dari hasil wawancara juga guru mengatakan bahwa model pembelajaran yang diterapkan yaitu PBL, Inquiry, atau PJBL. Model pembelajaran tersebut dapat merangsang dan melatih kemampuan guru dalam merancang proses pembelajaran yang berbasis masalah. Rahayu (2019) mengatakan bahwa model pembelajaran yang cocok untuk diaplikasikan dalam upaya meningkatkan hasil belajar kemampuan pemecahan masalah adalah model pembelajaran Problem Based Learning (PBL). Dilihat dari hasil kuesioner guru bahwa Indikator pemecahan masalah yang memiliki skor tertinggi yaitu pada indikator ke-9 memberi alasan strategi yang digunakan. Indikator ke-9 ini memperoleh skor 87,14\% dengan kategori sangat baik. Sedangkan Indikator pemecahan masalah yang memperoleh skor terendah dibandingkan 15 indikator lainnya yaitu pada indikator ke-6 mengidentifikasi asumsi dan ke-12 menggunakan analogi dengan perolehan skor 74,29\%. Walaupun memperoleh skor yang terendah namun masih dalam kategori baik.

Indikator yang memiliki skor tertinggi yaitu pada indikator ke-10 memecahkan masalah berdasarkan data dan masalah. Indikator ini memperoleh tingkat kategori baik dengan perolehan skor $78,4 \%$. Artinya bahwa siswa dapat dengan baik memecahkan masalah berdasarkan data 
dan masalah. Berdasarkan hasil observasi, data dan masalah yang diberikan guru berupa lembar kerja diskusi (LKD). KD merupakan bentuk dari lembar kerja siswa (LK) melalui LK siswa berkesempatan untuk mengemukakan temuan-temuan yang diperoleh pada saat diskusi (Wardhani, 2015). Selama diskusi, terjadi pertukaran informasi yang saling melengkapi sehingga siswa mempunyai pemahaman yang benar terhadap suatu konsep. Dari aktivitas ini siswa didorong agar belajar secara bermakna, tidak hanya menghafal atau mengikuti pengerjaan. Sedangkan indikator yang memperoleh skor terkecil dari hasil kuesioner siswa yaitu pada indikator ke-12 menggunakan analogi yang memperoleh skor 62,5\% dengan kategori baik. Walaupun memperoleh skor terendah namun masih memiliki kategori yang baik. Sama seperti data hasil kuesioner guru yang dimana skor terendah terdapat pada indikator ke-12. Namun indikator ini masih tergolong baik dalam pelaksanaannya. Penggunaan analogi ketika pembelajaran itu sangat penting. Karena perlunya pemahaman atau gambaran lebih terhadap suatu teori. Menurut Ayuningrum dan Endah (2016) pembelajaran biologi ini identik dengan praktikum, kegiatan praktikum penting dilakukan pada mata pelajaran Biologi dan diperlukan faktor pendukung agar kegiatan praktikum berjalan sesuai rencana. Faktor pendukung tersebut adalah keadaan ruang laboratorium yang nyaman serta alat dan bahan praktikum yang lengkap dan terawat. Karena praktikum cukup membutuhkan waktu yang lama, guru sering menganalogikan suatu teori dengan hal lain yang mudah dipahami oleh siswa.

\section{Faktor Yang Menghambat Pengembangan Keterampilan Pemecahan Masalah}

Berdasarkan hasil wawancara yang telah dilakukan oleh guru SMAN di Banten bahwa faktor yang menjadi penghambat berkembangnya keterampilan pemecahan masalah dalam pembelajaran biologi diantaranya yaitu: 1) kurangnya literasi membaca, berdasarkan hasil wawancara kondisi seperti itu memang hampir ditemukan di setiap sekolah, terkadang siswa terlihat tidak bersemangat dalam proses pembelajaran. Selain itu guru mengatakan bahwa minat membaca siswa yang rendah, dikarenakan siswa lebih asik bermain gadget dibandingkan membaca buku. Ketika minat membaca yang rendah terus dibiarkan maka dapat berpengaruh terhadap kurangnya pengetahuan siswa, karena pengetahuan dapat dijadikan suatu landasan siswa dalam menyelesaikan suatu permasalahan; 2) kurangnya motivasi siswa dalam belajar dan pelaksanaan pembelajaran yang masih menggunakan model pembelajaran konvensional. Yuliani (2013) mengatakan bahwa motivasi belajar dipengaruhi oleh lingkungan belajar siswa. Oleh karena itu, untuk menciptakan pembelajaran yang baik maka dibutuhkan lingkungan sekolah yang kondusif, kondusif secara lingkungan fisik dan juga sosial. Selain itu, pelaksanaan pembelajaran dengan model yang konvensional contohnya seperti penggunaan model pembelajaran dengan metode ceramah, ketika metode tersebut sering diterapkan maka siswa kurang memaksimalkan kreatifitas siswa dalam proses pembelajaran, karena siswa hanya 
mendapatkan informasi hanya dari guru mata pelajaran; 3) sarana dan prasarana yang kurang mendukung. Kondisi sarana dan prasarana yang didapat dari hasil wawancara bahwa, alat-alat elektronik seperti infokus, kondisi ruang kelas, yang masih terdapat belum memadai. Seperti pada sekolah A2, alat infokus yang masih terbatas penyediaannya. Minimnya sarana dan prasarana ini menyebabkan siswa hanya mengandalkan teori tanpa adanya realisasi yang nyata dalam proses pembelajaran, contohnya dalam belajar biologi tentang proses peredaran darah tentunya guru membutuhkan visualisasi seperti penayangan video pembelajaran tentang proses peredaran darah dalam tubuh manusia agar siswa dapat lebih memahami materi pembelajaran. Menurut Bahri (2018) salah satu faktor yang mempengaruhi rendahnya hasil pencapaian keterampilan pemecahan masalah siswa yaitu berasal dari dalam diri siswa itu sendiri. Minat membaca yang rendah dapat berpengaruh terhadap kurangnya pengetahuan siswa. Karena pengetahuan dapat dijadikan suatu landasan siswa dalam menyelesaikan suatu permasalahan.

\section{Perbandingan Hasil Observasi Dengan Kuesioner Keterampilan Pemecahan Masalah}

Berdasarkan hasil observasi dan kuesioner (Grafik 3) jika dilihat dalam poin per indikator terdapat beberapa skor yang tidak sesuai antara hasil observasi dengan hasil kuesioner. Hasil persentase skor yang memiliki perbedaan cukup signifikan seperti pada indikator ke-5 mendeskripsikan berbagai strategi dan indikator ke-11 membuat strategi lain. Data yang diperoleh dari hasil observasi pada indikator 5 memperoleh skor 14\% dengan kategori sangat kurang baik. Kemudian untuk hasil kuesioner memperoleh skor $77 \%$ dengan kategori baik. Selain itu, data yang diperoleh untuk indikator ke-11 hasil observasi memperoleh skor $14 \%$ dengan kategori sangat kurang baik dan hasil kuesioner memperoleh skor $76 \%$ dengan kategori baik.

Hasil analisis indikator dalam lembar observasi, tercatat bahwa guru tidak memberikan stimulus kepada siswa untuk merancang strategi dalam memecahkan masalah guru tidak membimbing siswa menemukan strategi baru (berbeda dari strategi sebelumnya) dalam menyelesaikan masalah. Proses pembelajaran yang diimplementasikan tidak menstimulus siswa untuk membuat strategi-strategi dalam memecahkan masalah. Hal tersebut diduga tingkat berpikir kreatif yang masih rendah, karena dalam berpikir kreatif menurut Laurita et al., (2018) dapat memahami serta menguasai masalah yang ada dan mampu menyelesaikan masalah dengan berbagai cara sesuai dengan ide. Proses pembelajaran yang diimplementasikan tidak mendorong atau kurang memberikan stimulus kepada siswa untuk mengeksplorasi dan melakukan berbagai investigasi dari berbagai perspektif masalah langsung. Rata-rata dari hasil kuesioner memiliki perolehan skor yang tinggi dibandingkan hasil observasi, menurut Setiawan et al., (1997) lembar penilaian diri rentan terhadap ketidak jujuran dalam pengisian kuesioner 
penilaian diri. Hal tersebut memunculkan indikasi bahwa terdapat ketidak jujuran terhadap pengisian kuesioner penilaian diri. Sehingga memunculkan skor yang berbeda. Akan tetapi perolehan skor yang didapat dari hasil kuesioner dan hasil observasi baik guru maupun siswa masih sama-sama tergolong dalam kategori yang baik dengan skor hasil observasi $65 \%$ dan $76 \%$ hasil kuesioner. Hal ini menandakan bahwa implementasi guru dalam proses pembelajaran yang mengembangkan keterampilan pemecahan masalah melalui pendekatan saintifik terhadap siswa sudah baik dengan hasil rerata skor $71 \%$ menurut acuan pengkategorian skor Widyoko (2009) jika persentase $81 \%$ - 100\% adalah berkategori sangat baik; $61 \%-80 \%$ berkategori baik; $41 \%$ $60 \%$ berkategori cukup; $21 \%$ - 40\% berkategori kurang; $\leq 20 \%$ berkategori sangat kurang baik.

\section{SIMPULAN}

Berdasarkan hasil penelitian yang telah dilakukan pada 7 SMA negeri di provinsi Banten, memperoleh hasil observasi sebesar 65\% dengan kategori baik dan hasil kuesioner sebesar $76 \%$ dengan kategori baik. Hal ini menandakan bahwa implementasi guru dalam mengembangkan keterampilan pemecahan masalah terhadap siswa sudah baik dengan rata-rata skor $71 \%$. Sehingga dapat disimpulkan bahwa proses pembelajaran biologi SMA dalam mengembangkan keterampilan pemecahan masalah melalui pendekatan saintifik pada 7 SMA negeri di provinsi Banten sudah berkategori baik.

Adapun faktor-faktor yang menghambat pengembangan keterampilan pemecahan masalah dalam proses pembelajaran biologi SMA di Banten yaitu 1) kurangnya literasi membaca; 2) motivasi belajar siswa yang rendah dan proses pembelajaran masih menggunakan model pembelajaran konvensional; 3) sarana prasarana yang kurang mendukung.

\section{UCAPAN TERIMA KASIH}

Terimakasih kepada para dosen pembimbing penelitian saya yang telah bersedia meluangkan waktunya untuk memberikan arahan terhadap penelitian saya, serta pihak yang telah berpartisipasi terhadap penelitian saya, terutama pihak sekolah SMAN $11 \mathrm{Kab}$. Tangerang, SMAN 20 Kab. Tangerang, SMAN 6 Kota Tangerang, SMAN 7 Kota Tangerang, SMAN 1 Pandeglang, SMAN 4 Pandeglang dan SMAN 1 Pamarayan.

\section{REFERENSI}

Ayuningrum, S., \& P. Endah. (2016). Analisis Hambatan Guru Biologi SMA Di Kota Semarang Dan Pemecahannya Dalam Implementasi Kurikulum 2013. Journal Of Biology Education. 5(1), 1-7.

Bahri, A., Putriana, D., \& Idris, I. S. (2018). Peran PBL dalam Meningkatkan Keterampilan Pemecahan Masalah Biologi. Sainsmat: Jurnal Ilmiah Ilmu Pengetahuan Alam, 7(2), 114-124.

Fitrianti, F. (2018). Prinsip Kontinuitas Dalam Evaluasi Proses Pembelajaran. Al-Ishlah: Jurnal Pendidikan.10(1),89-102. 
Kirom, A. (2017). Peran Guru Dan Peserta Didik Dalam Proses Pembelajaran Berbasis Multikultural. Jurnal Al-Murabbi.3(1),69-80.

Laksana, D. N. L., \& Dasna, I. W. (2017). Bagaimana Melakukan Penilaian Proses Pada Pembelajaran Berbasis Inquiry?. Journal of Education Technology. 1(4),224-230.

Laurita, S. E. A., Hobri, H., \& Murtikusuma, R. P. (2018). Analisis Kemampuan Berpikir Kreatif Siswa pada Materi Aritmetika Sosial Berbasis Jumping Task Ditinjau dari Gaya Kognitif Field Dependent dan Field Independent. KadikmA, 9(3), 171-182.

Lestari, I. D. (2020). Kemampuan Mahasiswa Calon Guru Pendidikan Biologi UNTIRTA dalam Pembuatan Soal Higher Order Thingking Skill (HOTS). Prosiding Seminar Nasional Pendidikan FKIP. 3(1), 126-128.

Mahdiyanto, A. Eko S. M. \& A.G. Tamrin. (2017). Perbandingan Penggunaan Model Pembelajaran Konvensional dan Model Pembelajaran Project Based Learning Terhadap Hasil Belajar Gambar Konstruksi Bangunan Siswa Kelas XI TGB A SMKN 2 Surakarta Tahun Ajaran 2016/2017. Indonesian Journal Of Civil Engineering Education, 3(1).

Miles, M.B., \& A.M. Huberman (2014). Analisis Data Kualitatif. Jakarta: Penerbit Universitas Indonesia (UI-Press).

Moleong, Lexy J. (2016). Metodologi Penelitian Kualitatif. Jakarta : Rosdakarya.

Napitupulu, E. E. (2008). Mengembangkan Strategi dan Kemampuan Siswa Memecahkan Masalah Matematik. Pythagoras: Jurnal Pendidikan Matematika, 4(2), 26-36.

Puspendik. (2019). Capaian Ujian Nasional Tahun Pelajaran 2018/2019. Diakses 24 November 2019, dari https://hasilun.puspendik.kemdikbud.go.id/

Rahayu, I. A. T. (2019). Mengembangkan Keterampilan Memecahkan Masalah Melalui Pembelajaran Berdasarkan Masalah. Journal Of Vocational And Technical Education (JVTE). 1(1), 1-6.

Reys, R. E., Suydam, M.N, Lindquist, M. M., \& Smith, N. L. (1998). Helping Children Learn Mathematics ( $5^{\text {th }}$ ed.). Usa : Allyn And Bacon.

Salim, A. (2014). Pendekatan saintifik dalam pembelajaran pendidikan agama islam (pai) di madrasah. Cendekia: Jurnal Kependidikan Dan Kemasyarakatan, 12(1), 33-48.

Setiawan, J. et al. (1997). Pengaruh Distorsi Motivasi Terhadap Tes Forced Choice. Psikologika: Jurnal Pemikiran dan Penelitian Psikologi. 2(2), 67-76.

Sufairoh. (2016). Pendekatan Saintifik Dan Model Pembelajaran K13. Jurnal Pendidikan Profesional. 5(3), 116-125

Sulasmono, B. S. (2012). Problem solving: Signifikansi, pengertian, dan ragamnya. Satya Widya, 28(2), 155-166. https://doi.org/10.24246/j.sw.2012.v28.i2.p155-166

Usman, U., Susilowati, S. M. E., \& Widiyaningrum, P. (2017). Analisis Kesesuaian RPP terhadap Pelaksanaan Pembelajaran Biologi dalam Mengembangkan Keterampilan Berpikir Kritis Siswa. Journal of Innovative Science Education, 6(2), 243-251.

Veronica, T., Swistoro, E., \& Hamdani, D. (2018). Pengaruh Pembelajaran dengan Model Problem Solving Fisika terhadap Hasil Belajar dan Kemampuan Pemecahan Masalah Fisika Siswa Kelas XI IPA SMAN 1 Lebong. Jurnal Kumparan Fisika, 1(2 Agustus), 3139.

Widyoko, E.P.S. (2009). Evaluasi Pembelajaran (Panduan Praktis Bagi Pendidik Dan Calon Pendidik). Yogyakarta : Pustaka Pelajar.

Winarti, W., Haerani, I., \& Muftianti, A. (2019). Penggunaan Model Pembelajaran Problem Based Learning dalam Upaya Meningkatkan Kemampuan Berpikir Kritis Matematis Siswa (Studi Kuasi Eksperimen Pada Siswa Kelas IV SDN 157 Sukaraja Kota Bandung). COLLASE (Creative of Learning Students Elementary Education), 2(1), 26-32. 